\title{
NÁLEZ BAROKNÍHO KORDU Z HABŘINY NA JAROMĚŘSKU VE VÝCHODNÍCH ČECHÁCH
}

\author{
PETR ŽÁKOVSKÝ - PAVEL DRNOVSKÝ
}

\begin{abstract}
Abstrakt: V roce 1922 byl na katastru obce Habřina v korytě říčky Hustíranky nalezen archeologický materiál, který sestával ze dvou koňských podkov, údajného torza přilby, kordu a bliže nespecifikovaného kosterního materiálu. Z těchto předmětů se dodnes podařilo jednoznačně identifikovat pouze krásně a takřka kompletně dochovaný kord se značkami na čepeli v podobě ř́šského jablka a tzv. pasovského vlka. Zbran̆ lze celkem jednoznačně datovat do prelomu 16. a 17., respektive prvních decennii 17. století. Nález tak lze hypoteticky spojit s pohnutými událostmi třicetileté války, které danou oblast zasáhly zejména ve 40. letech 17. století.
\end{abstract}

Klíčová slova: kord - nálezy z vodních toků-Pasov-Solingen-třicetiletá válka.

\section{The Find of a Baroque Rapier from Habřina in the Jaroměr Region, Eastern Bohemia}

Abstract: Archaeological material consisting of two horseshoes, a presumed fragment of a helmet, a rapier and unspecified skeletal remains was unearthed in the bed of the Hustiranka stream, in the cadastral zone of the Habrina village, in 1922. Of these items, only the beautifully and almost completely preserved rapier was reliably identified. The blade bears marks in the form of the imperial orb and the "Passau wolf". The weapon can be positively dated to the late 16th-early 17th century, or to the first decades of the 17th century. The find is hypothetically linked to the events of the Thirty Years' War that hit the region particularly hard in the 1640s.

Key words: rapier - finds from watercourses - Passau - Solingen - Thirty Years' War.

Nálezy raně novověkých chladných zbraní, respektive zbraní z průběhu 16. a 17. století, které by bylo možné alespoň $\mathrm{v}$ hypotetické rovině spojit $\mathrm{s}$ dlouhodobým válečným konfliktem známým obecně jako třicetiletá válka, nebylo v naší odborné literatuře publikováno prozatím př́lišs mnoho. Ve většině případů se navíc jedná o poměrně nedávné nálezy získané z velice prospěšné prospekce konfliktních areálů spojených s válečnými událostmi této pohnuté doby. Z těchto prospekcí, prováděných většinou pomocí detekční techniky, pocházejí však většinou jen torza těchto zbraní či jejich jednotlivé a solitérní části. Stačí zde uvést např́iklad nálezy několika hlavic kordů či zlomek čepele, které byly získány při prospekci areálu bitevního pole u Rakovníka (Šámal 2011, 56-59), nebo zlomek čepele z bitevního pole u Rozvadova (Matoušek 2011, 76; 2011a). Je příznačné, že z těchto situací pocházejí většinou právě jen poměrně nepatrné zlomky militarií, které jednoznačně svědčí o intenzivním sběru kovového materiálu více či méně bezprostředně po proběhlém vojenském střetu. Takto posbírané zbraně posloužily bud' jako vítaná kořist, či v př́ípadě jejich výrazného poškození jako zdroj kvalitní suroviny. Menší zlomky zbraní tak z pochopitelných důvodů spíše unikly pozornosti těmto tehdejším, dalo by se s nadsázkou říci, průkopníkům „battlefield archaeology“ než jejich podstatnější torza.

$\mathrm{K}$ archeologické transformaci celých zbraní či jejich větších zbytků tak dochází ve většině prrípadů pouze za specifických a, nutno říci, zcela ojedinělých podmínek. Tento fakt nás ostatně jako červená nit provází při studiu konfliktních areálů od pravěku až do současnosti. Pokud se zaměříme na průběh 17. století, lze za př́iklad takových vzácných nálezových okolností uvést takřka neskutečný objev v zákopu zasypaných dvou těl bojovníků s jejich kompletní výzbrojí a výstrojí, včetně mušket a pobočních chladných zbraní ve Stralsundu. Jeden z těchto neštastníků byl zabit patrně píkou či jinou zbraní rombického průřezu a druhý výstř̌elem z pistole do břišní krajiny patrně v průběhu vojenské kampaně z roku 1628 (např. Konze-Samariter 2014, 208-213, obr. 17-34). Za druhý př́klad si vezměme známou kolekci nálezů z bitevního pole u ukrajinského Berestečka, kde se spolu střetla v roce 1651 polská a kozácká vojska. Třídenní bitva zde proběhla ve výrazně podmáčeném terénu, takže řada zde ztracených militarií již nemohla být po bitvě sesbírána (Свешніков 1992, 225-269). 


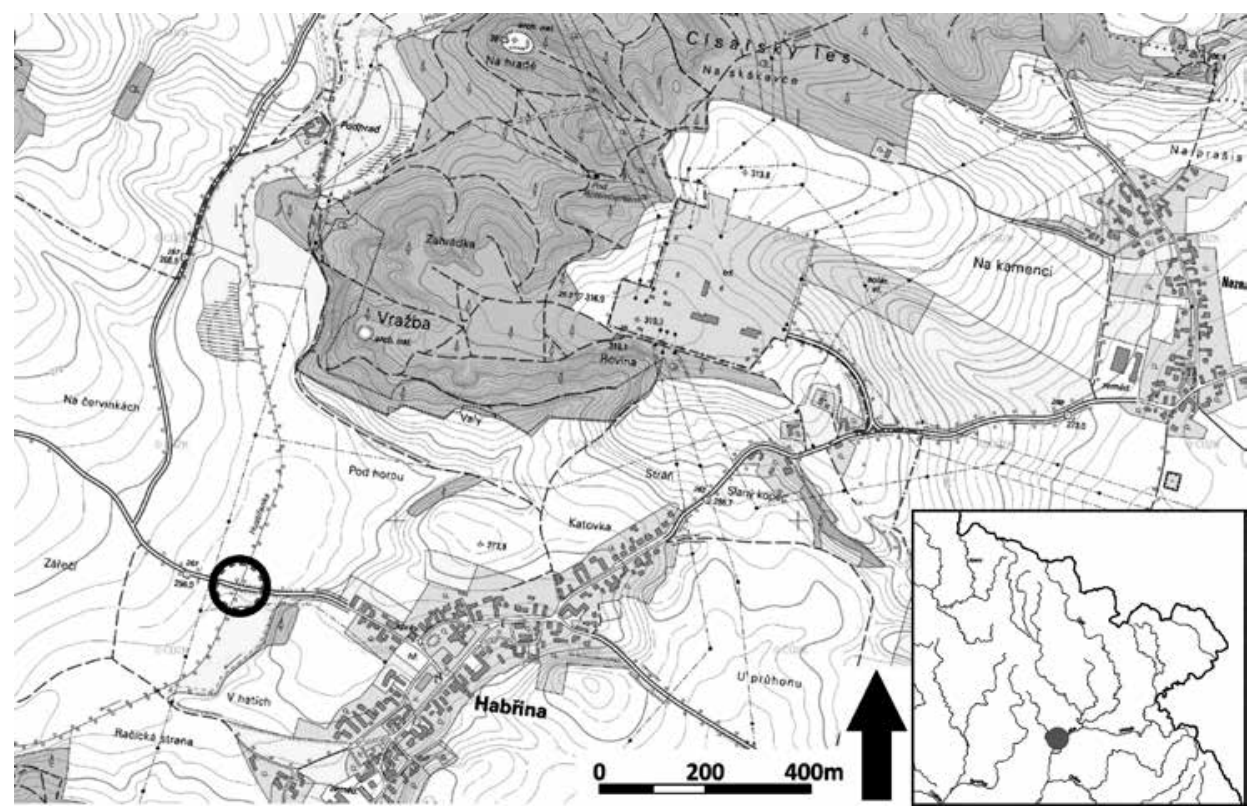

Obr. 1. Vesnice Habřina a její nejbližší okolí. Místo nálezu kordu vyznačeno přerušovaným kruhem. Zdroj ZM 10 @ ČÚZK. Abb. 1. Das Dorf Habřina und seine nächste Umgebung. Die Fundstelle des Degens ist mit einem gepunkteten Kreis gekennzeichnet. Quelle Grundkarte 10 @ ČÚZK.

Z našeho území takto výjimečné nálezové situace a s nimi spojené soubory, v nichž by byly zastoupeny i podstatnější torza chladných zbraní, prozatím postrádáme. Především díky prováděnému soupisu středověkých a raně novověkých militarií z území České republiky máme sice již k dispozici poměrně značné množství archeologizovaných kordů a jejich torz z průběhu 16. a 17. století, $\mathrm{k}$ naprosté většině $\mathrm{z}$ nich však postrádáme jakékoliv informace o jejich nálezových okolnostech a ve většině př́ípadů i elementární údaje o místě jejich nálezu. Obecně se dá říci, že z prozatím podchycených zhruba 30 nálezů kordů a jejich zlomků z území Moravy, Českého Slezska a východních Čech máme relevantní informace o místě jejich nálezu pouze u jedné třetiny z nich. Tím je pochopitelně radikálně snížena vypovídací schopnost těchto předmětů. Původně tak tomu bylo i u velice kvalitně dochovaného kordu, který byl při prováděném soupisu militarií objeven ve sbírkách Městského muzea v Jaroměři. $\mathrm{K}$ dané zbrani, respektive $\mathrm{k}$ jejím nálezovým okolnostem, se však podařilo v archivu Archeologického ústavu v Praze dohledat velice důležité informace, které nám dovolují vyslovit i jisté, byt’ pouze čistě hypotetické úvahy o jeho archeologizaci.

\section{Místo nálezu kordu a jeho nálezové okolnosti}

Nález kordu je prvně uveden v oznámení holohlavského děkana J. F. Seidla ze 17. června $1922,{ }^{1}$ které zpravuje o objevu koster v Holohlavech a zároveň informuje o vykopání zbraně, o které mluví jako o meči, během stavby silničního mostu u Habřiny. Vlastní nález zbraně měl být učiněn $\mathrm{v}$ době před 14. červnem roku 1922. Společně se zbraní měl být údajně nalezen i blíže neurčený kosterní materiál a zachovalá sláma. V reakci na tuto zprávu byl 28. června pracovníky tehdejšího Archeologického ústavu vznesen dotaz o doplnění nálezových informací. Druhou

1 Archiv ARÚ AV ČR, Praha, v. v. i., čj. 173/22. 


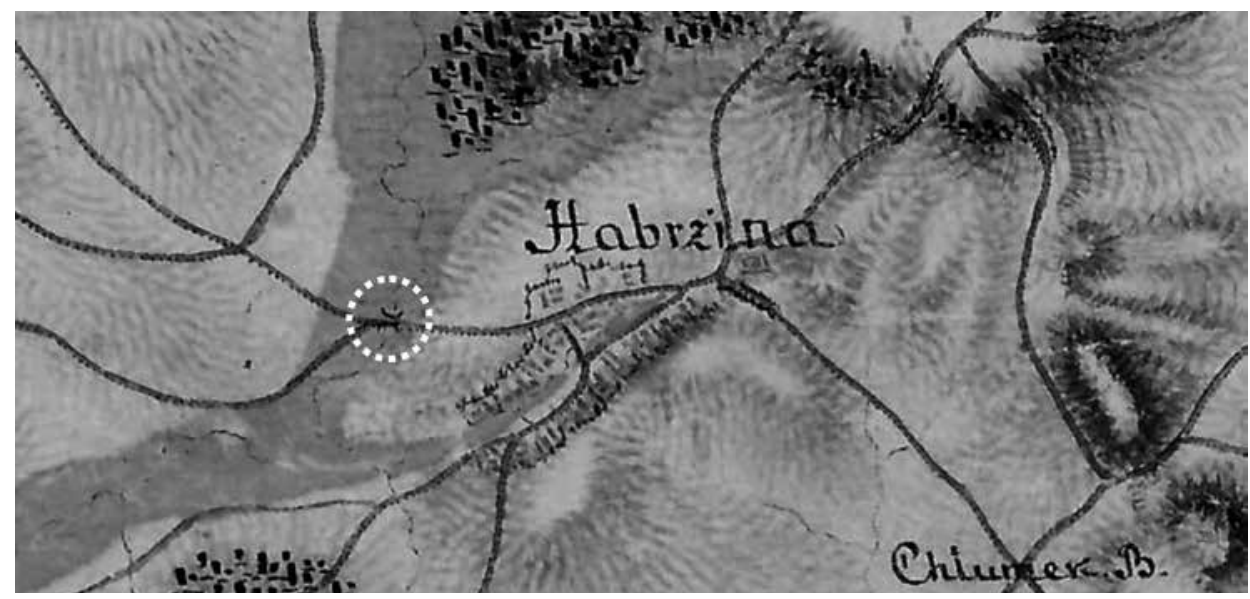

Obr. 2. Místo nálezu zachycené při I. vojenském mapování. Cesta překonává říčku Hustířanku pomocí mostku na stejném místě jako dnes. Zdroj http://mapire.eu.

Abb. 2. Bei der I. militärischen Kartierung erfasste Fundstelle. Der Weg führt an der gleichen Stelle wie heute mittels einer Brücke über den kleinen Fluss Hustířanka. Quelle http://mapire.eu.

zprávu ze dne 7. července sepsal místopředseda Okresní správní komise v Jaroměři K. Pišnák. ${ }^{2}$ V tomto dopisu jsou rozvedeny nálezové okolnosti a popis kordu, který je i nadále označován jako meč. Podle doplněných údajů byl objev učiněn dělníky v hloubce $1,5 \mathrm{~m}$ v sedimentech ř́ičky Hustíranky. Zbraň je popsána jako velmi zachovalá, dokonce bylo v době nálezu stále př́ítomno dřevěné obložení rukojeti, které se však brzy po vyzvednutí rozpadlo. Zmíněny jsou i značky ve tvaru říšského jablka a vlevo běžícího zvířete. Společně s kordem byly objeveny dvě koňské podkovy a vrchol rytířského šišáku, který však byl velmi porušený. Přítomnost kostí a slámy, které jsou zmíněny v první zprávě, již uvedena není. V dovětku se dále píše, že meč je vystaven v kanceláři Okresní správní komise v Jaroměři a následně bude předán do jaroměřského muzea, což bylo posléze skutečně splněno.

Vlastní místo nálezu se nachází západně od intravilánu obce Habřina u mostu přes Hustířanku na cestě do sousedních Lužan (obr. 1-2). Jedná se sice spíše o lokální komunikaci, je však dobře dostupná z hlavní dálkové cesty, jež prochází z Hradce Králové na Jaroměř a pokračuje dále na Náchod či Trutnov. Tím umožňuje spojení s Kladskem a Horním Slezskem. Z této silnice se naše cesta vyděluje v Holohlavech u Smiřic a přes Habřinu by bylo možno pokračovat sice po menších, ale poměrně přímých cestách na Hořice, či Miletín, nebo se napojit na komunikaci mezi Jaroměří a Velichovkami. Každopádně mohla být tato cesta využita jako poměrně přímé spojení mezi Jaroměřskem a Jičínskem.

\section{Kord - jeho klasifikace, analogie a datování}

Jedná se o velice kvalitní a výborně zachovalou zbraň ${ }^{3}$ o celkové délce $1110 \mathrm{~mm}$, která je vybavena poměrně masivní čepelí o délce $938 \mathrm{~mm}$ (obr. 3-6). Šírka čepele se směrem k nevýraznému hrotu jen nepatrně parabolicky zužuje z 33 na $26 \mathrm{~mm}$. Vlastní hrot je pak vytvořen poměrně krátkým a výrazným zkosením hran čepele. Tloušt'ka čepele se směrem $\mathrm{k}$ hrotu plynule

2 Archiv ARÚ AV ČR, Praha, v. v. i., čj. 198/22.

3 Městské muzeum Jaroměř, inv. č. 17755, př. č. 3482. Za umožnění studia zbraně srdečně děkujeme zaměstnancům muzea, především panu Davidovi Doubravovi. 


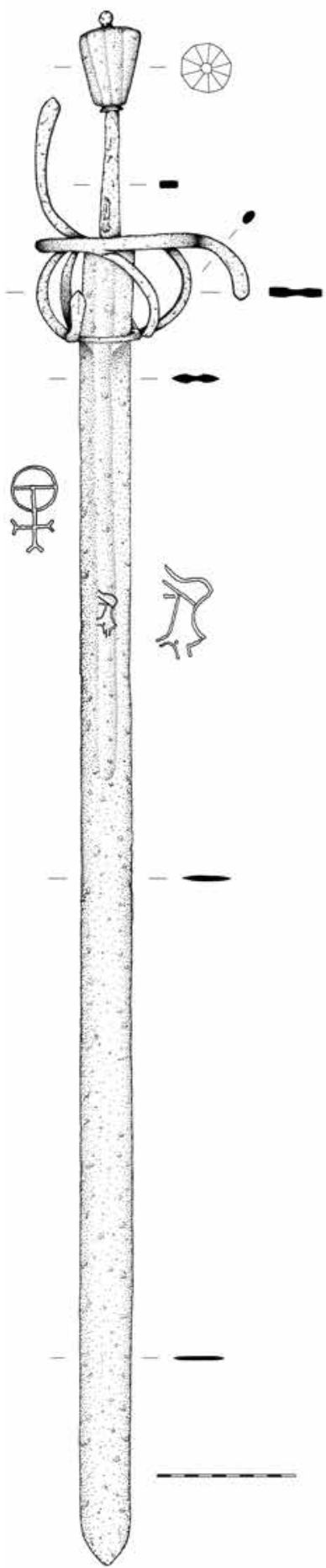

Obr. 3. Kord z Habřiny. Kresba P. Žákovský. Abb. 3. Degen aus Habřina. Zeichnung P. Žákovský. zužuje z původních 5 na $1 \mathrm{~mm}$ u hrotu. Čepel je vybavena $53 \mathrm{~mm}$ dlouhým ricassem, které není od vlastní čepele výrazněji odsazeno. Jeho šířka se směrem od ochranného koše zbraně plynule a poměrně nevýrazně rozšiřuje z 30 na $32 \mathrm{~mm}$. Tloušt'ka ricassa činí $6 \mathrm{~mm}$. Čepel je dále opatřena poměrně širokým, mělkým a nevýrazně ohraničeným oboustranným Žlábkem. Žlábek částečně začíná již na ricassu čepele a je ukončen zhruba před polovinou její celkové délky. Dále pak čepel získává nevýrazně šestiboký, místy až čočkovitý průřrez. Na lícní ploše hrubí je čepel opatřena výraznou a poměrně rozměrnou rytou značkou v podobě vlevo běžícího zvířete - tedy tzv. pasovského vlka (obr. 10:1). Na rubové ploše hrubí pak nalezneme opět značně rozměrnou rytou značku v podobě ř́ššsého jablka (obr. 10:2). Kvalitní dochování čepele podtrhuje i fakt, že u obou výrobních značek se dodnes dochovala většina tauzie provedené drátkem vyrobeným ze žlutého kovu.

$\mathrm{Na}$ krátký řap o délce $172 \mathrm{~mm}$, jehož šírka se směrem vzhůru plynule parabolicky zužuje ze 17 na $7 \mathrm{~mm}$, přičemž jeho tloušt'ka se stejným směrem zužuje z 6 na $4 \mathrm{~mm}$, je nanýtována poměrně masivní desetiboká hlavice přibližně kónického tvaru. Hlavice je vybavena spodním plastickým prstencem a svrchním ozdobným, přibližně kulovitým knoflíkem, na jehož svrchní ploše je dobře patrná roznýtovaná závěrná hlava řapu. Hlavice je nevýrazně fasetována do deseti vertikálních polí. Délka hlavice dosahuje $66 \mathrm{~mm}$, přičemž její šířka se směrem ke svrchní rovné bázi plynule rozšiřuje z 23 na $43 \mathrm{~mm}$, obdobně jako její tloušt'ka, jež činí 21-39 mm. Řap byl v době nálezu údajně ještě opatřen původním dřevěným obložením rukojeti, které se však při vyzvednutí zbraně bezezbytku rozpadlo.

$\mathrm{Na}$ řap je navlečen ochranný koš sestávající z přibližně $185 \mathrm{~mm}$ dlouhé záštity s vertikálně esovitě prohnutými rameny obdélného průřezu $\mathrm{s}$ fasetovanými hranami, přičemž zadní rameno záštity je výrazně zahnuto směrem dolů $\mathrm{k}$ čepeli, kdežto přední přechází plynule ve hřbetní oblouk. Na lícní straně je záštita doplněna lícním horizontálním záštitným prstencem a dále dvěma prstýnky, jež jsou na spodních okrajích opatřeny výraznými kostkami a jsou spojeny spodním, výrazně menším horizontálním prstencem. $\mathrm{Z}$ předního 


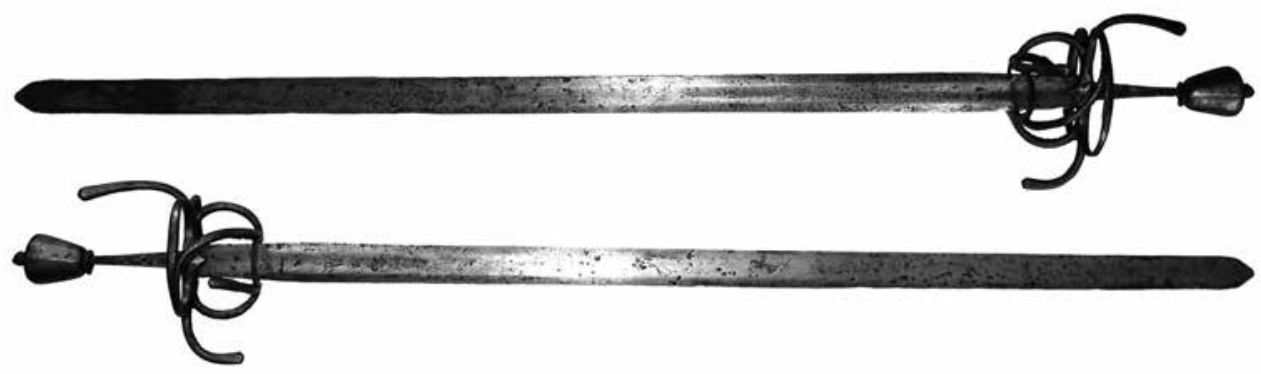

Obr. 4. Celkové pohledy na kord z Habřiny. Foto P. Žákovský.

Abb. 4. Gesamtansichten des Degens aus Habřina. Foto P. Žákovský.
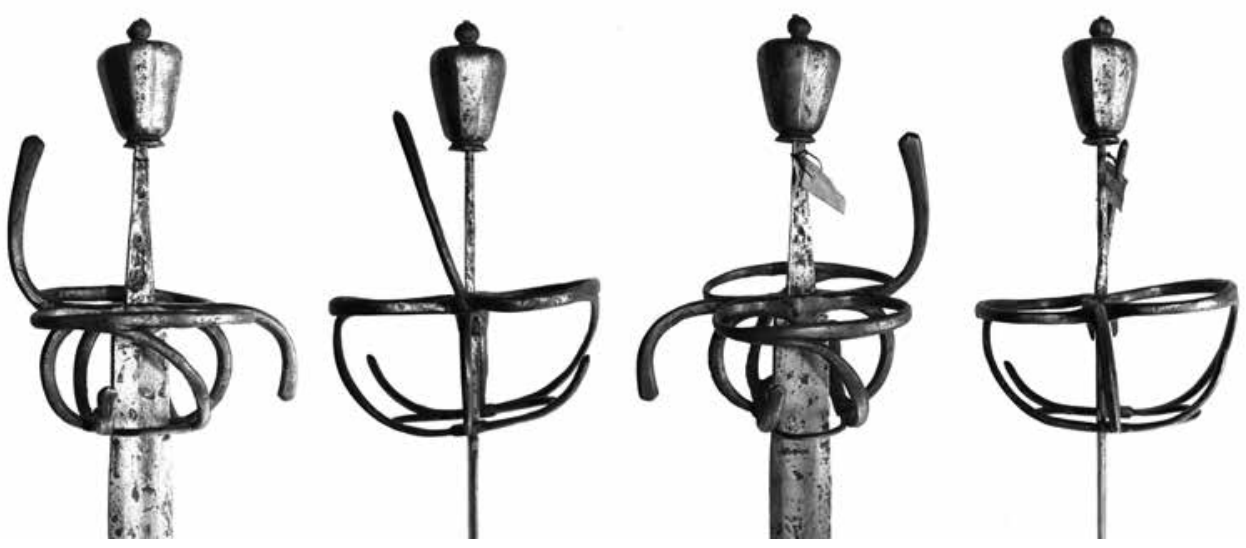

Obr. 5. Detaily garnitury rukojeti kordu z Habřiny. Foto P. Žákovský.

Abb. 5. Details des Griffteils des Degens aus Habřina. Foto P. Žákovský.

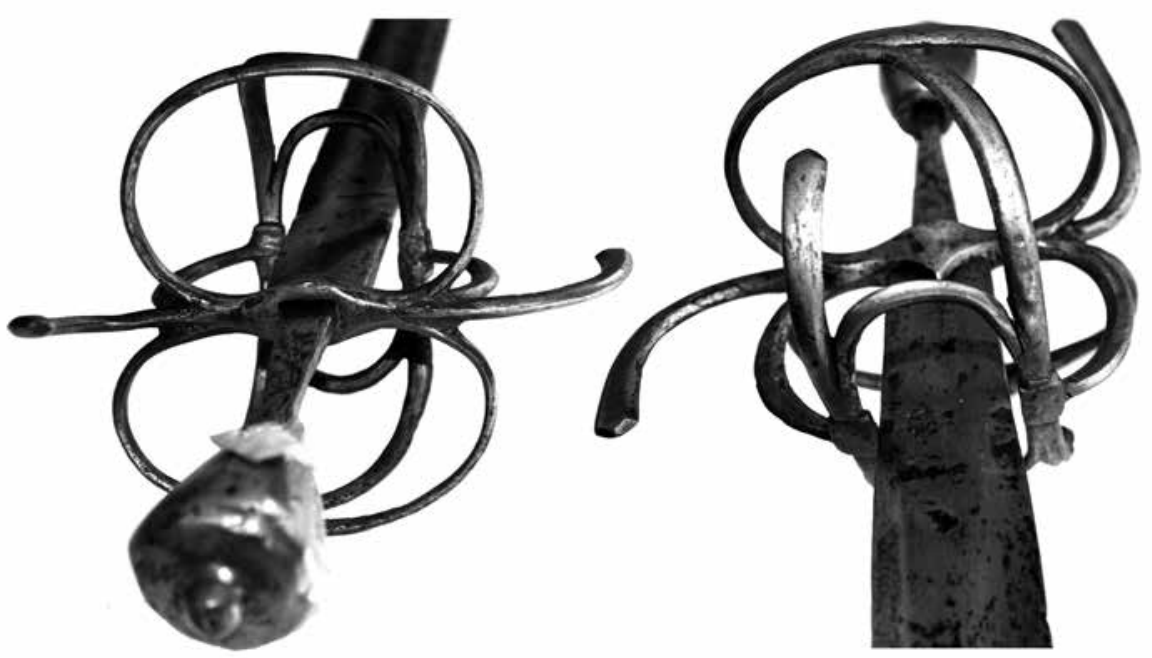

Obr. 6. Detaily garnitury rukojeti kordu z Habřiny. Foto P. Žákovský.

Abb. 6. Details des Griffteils des Degens aus Habřina. Foto P. Žákovský. 
prstýnku, respektive z jeho kostky, vyrůstá jeden krátký vertikální prut, částečně vyplňující a chránící prostor mezi oběma horizontálními záštitnými prstenci. Ze zadního prstýnku vyrůstá podobný prut, který je však oproti předchozímu diagonálně protažen a kovářsky spojen se svrchním horizontálním záštitným prstencem. Tato poměrně složitá konstrukce lícní strany ochranného koše zajišt'ovala již značně dokonalou ochranu ruky svého majitele. Zbývá se ještě zmínit o rubové straně koše. Zde se však můžeme omezit pouze na konstatování, že ta je konstruována zcela analogicky jako jeho lícní strana. Celý ochranný koš je konstruován ze železných prutů přibližně obdélného průřezu s výrazně zkosenými hranami, takže místy je jejich průřez až šestiboký. Šírka prutů kolísá zhruba mezi $6-8 \mathrm{~mm}$ a tloušt'ka osciluje kolem $6 \mathrm{~mm}$.

Celková hmotnost zbraně dosahuje $1242 \mathrm{~g}$, přičemž její těžiště bylo naměřeno ve vzdálenosti přibližně $120 \mathrm{~mm}$ od záštity.

Již na první pohled na studované zbrani zaujme její takřka perfektní stav dochování, čehož si ostatně nemohl nevšimnout také autor nálezové zprávy z roku 1922. Obecně by se dalo říci, že se na zbrani výrazněji neprojevila její archeologická transformace a nebýt výše zmíněné nálezové zprávy, dalo by se o její archeologizaci pochybovat. Díky stavu zbraně tak můžeme s jistotou říci, že garnitura její rukojeti nebyla původně nijak výrazněji zdobena, jak se s tím setkáváme na řadě analogických exemplářů ze světových sbírek. Kord z Habřiny tedy můžeme s největší pravděpodobností přiřadit spiše k prostším, přesto však nepochybně kvalitním vojenským zbraním.

Zbraň lze spolehlivě na základě tvaru koše přiřadit ke kordům s garniturami rukojetí typu 31 podle Normana, který jejich výskyt spatřuje především v průběhu první poloviny 17. století (Norman 1980, 94-95). Obdobně datuje analogické ochranné koše E. Oakeshott, který je začlenil do skupiny D tzv. polovičních košů (Oakeshott 2000, 137-138). Poměrně spolehlivé chronologické zařazení studovaného typu kordu, respektive jeho ochrany ruky, nám navíc umožňuje několik dochovaných ikonografických pramenů, které jsou vesměs datovány právě do počátku či prvních dekád 17. století (srov. Norman 1980, 94-95). Za všechny zde stačí uvést realistické znázornění kordu, kterým je vyzbrojena postava Boudewijna van Offenberg na skupinovém portrétu důstojnického sboru haarlemské městské gardy sv. Jorise. Na tomto obraze z dílny Franse Halse z roku 1616 je předmětný důstojník vyobrazen s kordem, jehož garnitura rukojeti je patrně zdobena plošným zlacením. Zbraň v pochvě má postava zavěšenou na typickém širokém bandalíru u levého boku, přičemž znázorněný boční opasek i plocha obou křídel bud' látkového či koženého bandalíru je zdobena stylizovanou vegetabilní výzdobou (napr. North 1993, 58; obr. 7:1). Tento obraz nám tak názorně ukazuje jak vlastní typ zbraně, tak také její nejběžnější způsob nošení. Obdobným bandalírem, tentokráte patrně z černěné kůže, je vybaven i kord studovaného typu z obrazu Jacoba Lyona z roku 1628, který nám představuje členy amsterdamské střelecké jednotky kapitána Jacoba Pietersze Hooghkamera a poručíka Pietera Jacobsze van Rijn (např. Meijer 2013, 13, obr. 13; obr. 7:2).

Datování daného druhu ochranných košů do počátku 17., respektive přelomu 16. a 17. století ostatně jednoznačně dokazuje i řada kompletně dochovaných exemplářů, u kterých známe i jejich původní zadavatele a majitele. Mnohdy jsou tyto zbraně, respektive garnitury jejich rukojetí, velice bohatě zdobeny různými kombinacemi výzdobných technik. Tyto luxusní zbraně byly totiž většinou určeny špičkám tehdejší společnosti. V této souvislosti lze uvést především přepychový kord, jenž patřil do výzbroje dánského krále Kristiána IV. a který dnes nalezneme ve sbírkách zámku Rosenborg v Kodani. Tato zbraň o celkové délce $1103 \mathrm{~mm}$, která byla vyrobena někdy kolem roku 1600, má garnituru rukojeti zdobenu plošným zlacením a tauzovanou výzdobou se stylizovaným vegetabilním ornamentem doplněným na čelní ploše hlavice emailovaným královským monogramem „C4“ (nap̌r. Blair 1962, 85, obr. 101; Norman 1980, 95). Plošným stř́břením je zdobena garnitura rukojeti kordu vyrobeného před rokem 1605, jenž byl součástí pohřební výbavy Erika Valkendorfa til Glorup v katedrále v Roskildu (např. Norman 1980, 95).

Poněkud zvláštní místo v daném typu ochranných košů zaujímá nepochybně přepychový kord s kompletně dochovanou pochvou i bandalírem ze sbírek proslulé drážd’anské sbírky zbraní. Tato zbraň má plošně zlacenou garnituru rukojeti posázenou navíc větším množstvím broušených tyrkysů, přičemž na ecussonu je záštita zdobena saským a brandenburským erbem pro- 

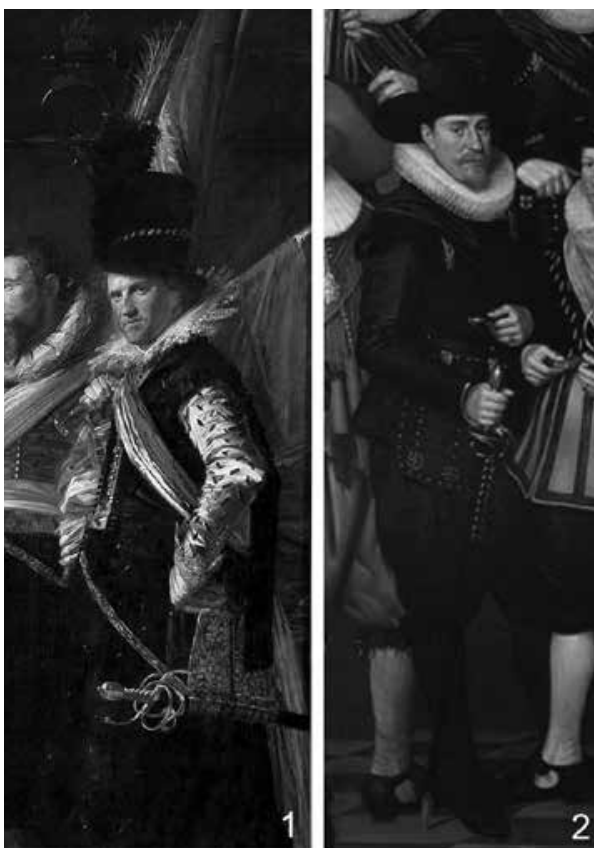

Obr. 7. Ikonografické prameny ke kordům s ochrannými koši typu 31. 1 - výřez z obrazu Franse Halse z roku 1616 , který zobrazuje důstojnický sbor haarlemské městské gardy sv. Jorise (podle North 1993, 58); 2 - výřez z obrazu Jacoba Lyona $z$ roku 1628, který nám představuje členy amsterdamské střelecké jednotky kapitána Jacoba Pietersze Hooghkamera a poručíka Pietera Jacobsze van Rijn (podle Meijer 2013, obr. 13).

Abb. 7. Ikonographische Quellen zu Degen mit Korbhandschutz des Typs 31. 1 - Ausschnitt aus einem Gemälde von Frans Hals aus dem Jahr 1616, auf dem das Offizierskorps der Schützengilde St. Jorrit von Haarlem dargestellt wird (nach North 1993, 58); 2 - Ausschnitt aus einem Gemälde von Jacob Lyon aus dem Jahr 1628, das uns die Mitglieder der Amsterdamer Schützeneinheit Hauptmann Jacob Pietersz Hooghkamer und Leutnant Pieter Jacobsz van Rijn vorstellt (nach Meijer 2013, Abb. 13). vedeným v emailu. Zdá se však, že celá zbraň nebyla vyrobena v jedné dílně. Garnitura rukojeti, jejíž původ lze hledat někde v saské oblasti, patrně přímo u některých drážd'anských mistrů, byla totiž aplikována na čepel značenou toledským mečířem Pedrem de Velmonte. Podle údajů původních inventářů drážd'anské zbrojnice byla tato zbraň darována saskému kurfiřtovi Kristiánovi II. jeho matkou těsně před Vánocemi roku 1605 (Haenel 1923, 102, tab. 51:b, 51A; Norman 1980, 95; Schöbel 1982, 16, obr. 19).

Bohatě zdobena byla pochopitelně i celá řada kordů, respektive jejich garnitur rukojetí, které byly sice určeny tehdejší nobilitě, jejichž konkrétního původního majitele však dnes již neznáme. Můžeme zde uvést např́íklad kord ze sbírek Wallace Collection, jehož garnitura rukojeti je zdobena černěním a patrně zlatou tauzií v podobě arabeskových motivů a oválných kartuší s lidskými postavami (Mann 1962, 317-318, tab. 120; Norman 1980, 95, obr. 49). Podobně jsou zdobeny rovněž analogické ochranné koše na dvou kordech ze sbírek drážd’anské zbrojnice, přičemž jeden z nich je vybaven čepelí z dílny solingenského mečíře Clemense Meigena, která byla zhotovena někdy kolem roku 1590 (Ehrenthal 1897, 74; Seitz 1965, 313, obr. 219; Norman 1980, 95, obr. 51). Také ochranný koš kordu ze sbírek Castello di Monselice nese na své čelní ploše jemnou rytou a plátovanou výzdobu v podobě vegetabilního vzoru (Hayward 1980, 53, kat. č. 151, obr. 114) a garnitura rukojeti kordu z bývalé sbírky Carla von Schwerzenbach je na lícní straně zdobena důmyslnou gravírovanou výzdobou s geometrickými motivy (Forrer 1905, 59, tab. LIII:2).

Ve větší míře se na kordových ochranných koších studovaného typu objevuje výzdoba $\mathrm{v}$ podobě celoplošného pokovení. Tímto způsobem je zdobena např́íklad zbraň s čepelí z milánské dílny Antonia Piccinina ze sbírek Deutsches Historisches Museum v Berlíně (např. MüllerKölling 1984, 378, obr. 139), kord ze sbírek Metropolitan Museum of Art v New Yorku (Nickel 1974, 168) či zbraň s čepelí od pasovského mečíře Clemense Stamma z bývalé Kounicovy sbírky (Fischer 1936, 2, kat. č. 11, tab. 4).

Nejvíce ochranných košů studovaného typu však jakoukoliv výzdobu postrádá, tedy pokud nebudeme za výzdobu považovat vlastní profilaci ramen. Takových zbraní je registrováno ze světových oficiálních i soukromých sbírek poměrně velké množství. Několik zbraní s podobnou ochranou ruky známe rovněž z českých a moravských sbírek. Podobným nezdobeným, ale černěným košem je vybaven např́iklad kord ze sbírek Městského muzea v Moravském Krumlově (Žákovský 2011, 148-149, tab. VIII) či jeden kord ze zbrojnice zámku v Lysicích (Kočan-Gronský 2014, 27, kat. č. 7). V píseckém muzeu se dokonce nachází bliže nelokalizovaný archeologický nález kordu s podobným ochranným košem. Větší počet dochovaných zbraní s předmětným 

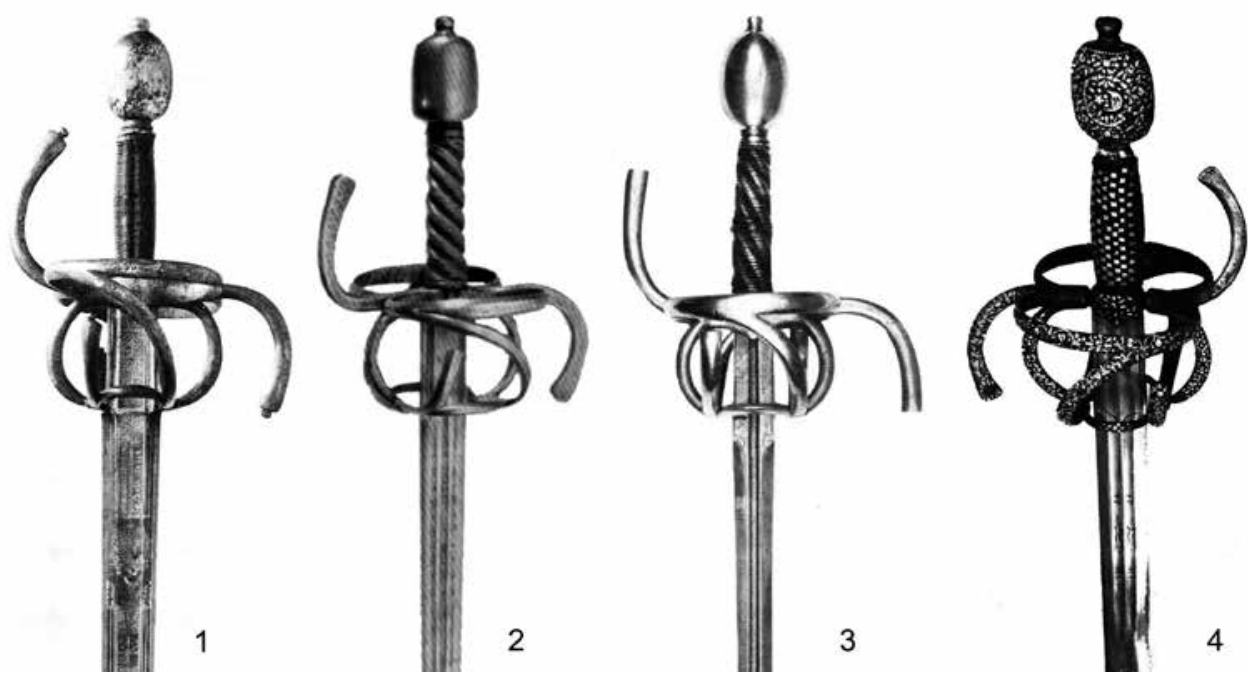

Obr. 8. Kordy s analogickými konstrukčními variantami ochranných košů. 1 - kord Gustava Adolfa ze sbírek Livrustkammaren Stockholm (podle Nordström 1984, kat. č. 19); 2 - kord s čepelí z dílny Andrei Farrary (podle Hermann a kol. 2007, kat. č. 3892); 3 - nesignovaný kord ze soukromé sbírky (podle Hermann-Wagner-Czerny 1988, kat. č. 855); 4-bohatě zdobený kord s čepelí z dílny Petera Hoppeho ze sbírek Deutsches Historisches Museum Berlin (podle Müller-Kölling 1984, obr. 142).

Abb. 8. Degen mit ähnlichen Konstruktionsvarianten des Korbhandschutzes. 1 - Degen von Gustav Adolf aus den Sammlungen der königlichen Rüstkammer Livrustkammaren Stockholm (nach Nordström 1984, Kat. Nr. 19); 2 - Degen mit einer Klinge aus der Werkstatt von Andrea Farrara (nach Hermann et al. 2007, Kat. Nr. 3892); 3 - unsignierter Degen aus einer Privatsammlung (nach Hermann-Wagner-Czerny 1988, Kat. Nr. 855); 4 - reichverzierter Degen mit einer Klinge aus der Werkstatt von Peter Hoppe aus den Sammlungen des Deutschen Historischen Museums Berlin (nach Müller-Kölling 1984, Abb. 142).

typem ochrany ruky tak jednoznačně dokládá jejich značnou oblibu v takřka celé západní, severní a střední Evropě. Z území jižní Evropy prozatím těchto typů nemáme registrováno příliš mnoho, což by mohlo naznačovat cosi o jejich původu. Někdy jsou zbraně s tímto typem ochrany ruky totiž považovány za výrobky saských dílen (např. Nickel 1974, 168; Müller-Kölling 1984, 378; Hilbert 1998, 50), ovšem dosavadní stav poznání nás k tomuto jednoznačnému závěru nijak neopravňuje. Spíše naopak. Žrejmě se prozatím budeme muset spokojit s poněkud obecným závěrem, že zbraně tohoto typu mohly být vyráběny na přelomu 16. a 17. století lokálními dílnami po celé střední, západní a severní Evropě.

Oproti kordu z Habřiny se přeci jen většina uvedených či obecně známých zbraní tohoto typu poněkud odlišuje, a to konstrukcí, respektive tvarem své rubové strany. Variabilita konstrukčních variant je poměrně široká a tvoři ji dva až tři různě kombinované rubové záštitné pruty. U kordu z Habřiny se však setkáváme s variantou, kdy lícní i rubovou stranu koše tvoří analogická sestava prutů. Takto konstruovaných ochranných košů neznáme dosud př́íliš mnoho. Můžeme zde uvést např́klad prozatím blíže nepublikovanou zbraň ze sbírek Germanisches Nationalmuseum Nürnberg (inv. č. W 1374) či poměrně masivní zbraň s bohatě zdobenou čepelí z dílny solingenského mečíre Johannese Wundese ze sbírek Livrustkammaren ve Stockholmu. Garnitura rukojeti této zbraně je plošně postříbřena a původně měla být údajně v majetku Gustava Adolfa (Norman 1980, 95; Nordström 1984, 38, kat. č. 19; obr. 8:1). Kord s identickým ochranným košem a čepelí z dílny bellunského mečíře Andrei Farrary byl také před nedávnem dražen jednou renomovanou aukční síní v Mnichově (Hermann a kol. 2007, 532-533, kat. č. 3892; obr. 8:2). Obdobnou, tentokráte nesignovanou zbraň dražila zmíněná aukční síň již koncem 80. let 20. století (Hermann-Wagner-Czerny 1988, kat. č. 855; obr. 8:3). Stejným typem ochranného koše je vybavena rovněž zbraň ze sbírek Deutsches Historisches Museum v Berlíně, 
jejíž garnitura rukojeti je bohatě zdobena plošným černěním a stř́ibrnou tauzií v podobě vegetabilního a geometrického vzoru, přičemž její čepel pochází z dílny solingenského mečíře Petera Hoppeho (napřr. Weyersberg 1926, 21; Müller-Kölling 1984, 378, obr. 142; obr. 8:4).

Asi nejbližší analogii ke kordu z Habřiny tak představuje zbraň, jež byla dříve součástí sbírek císařské vídeňské zbrojnice a dnes je uložena v Magyar Nemzeti Múzeum v Budapešti. Je to zbraň o celkové délce $1120 \mathrm{~mm}$ a hmotnosti $1100 \mathrm{~g}$, která je opatřena masivní čepelí tradicí připisovanou uherskému králi Matyáši Korvínovi, jenž ji měl využít mimo jiné i při dobývání Vídně v roce 1485. Zřejmě s touto zbraní lze spojit dopis z ledna roku 1491, kterým císař Maxmilián I. sděluje arcivévodovi Zikmundu Tyrolskému, že mu posílá dělo a meč Matyáše Korvína. Počátkem 17. století byl s největší pravděpodobností tento meč upraven do dnešní podoby, přičemž původní čepel meče byla opatřena novou garniturou rukojeti, která již nerespektovala původní podobu zbraně (např. Boeheim 1894, 5; Szendrei 1896, 295; Kalmár 1971, 68). Pro tuto variantu by mohl svědčit tvar čepele a její rozměry, které opravdu vykazují znaky starší mečové čepele. Pouze ve svrchní části byla upravena do poměrně nepravidelného, výrazně zúženého ricassa. Její dochovaná délka dosahuje $870 \mathrm{~mm}$ a maximální šířka až $50 \mathrm{~mm}$. S takto širokou čepelí se u kordů ze závěru 16. a počátku 17. století setkáváme opravdu jen velice zřídka. Po obou plochách čepele se nalézá taktéž zřejmě raně novověký rytý, původně zřejmě tauzovaný nápis, který na jedné straně zní: „MATIAS CORVINVS REX VNGARIAE“ a na druhé pak „PRO REGE DIVINA LEGE ET GREGE“. Zbraň má jinak naprosto stejně konstruovaný koš jako zbraň z Habřiny, včetně profilace jednotlivých prutů. Od studované zbraně se v tomto ohledu

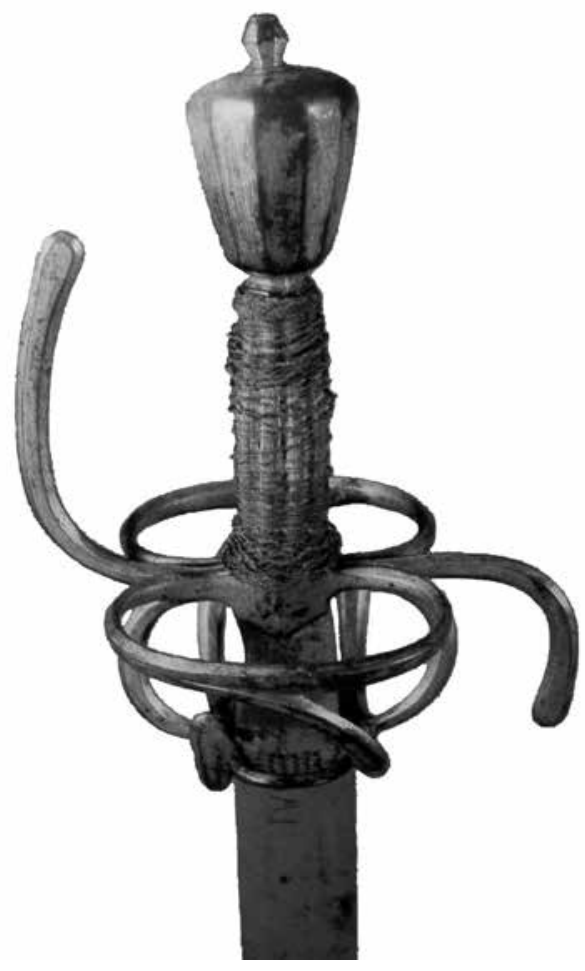

Obr. 9. Detail garnitury rukojeti tzv. meče Matyáše Korvína ze sbírek Magyar Nemzeti Múzeum Budapest. Podle Lugosi-Temesváry 1988, kat. č. 64 .

Abb. 9. Detail des Griffteils des sog. Schwertes von Matthias Corvinus aus den Sammlungen des Magyar Nemzeti Múzeum Budapest. Nach Lugosi-Temesváry 1988, Kat.-Nr. 64. odlišuje pouze tím, že je jeho celá garnitura rukojeti silně pozlacena (např. Boeheim 1889, 30, kat. č. 87; 1894, 5-6, tab. VII:3; Szendrei 1896, 295-296, kat. č. 1189; Kalmár 1971, 68, obr. 118-119; Norman 1980, 95; Lugosi-Temesváry 1988, kat. č. 64; obr. 9).

Kord z Habřiny je dále vybaven poměrně masivní hlavicí přibližně kónického tvaru, respektive tvaru komolého kužele, jejíž plášt' je poměrně nevýrazně hraněn a rozčleněn do celkem deseti vertikálních polí. Nejvíce se tak asi blíží hlavicím typu 38 podle A. Normana, který jejich největší oblibu spatřoval $\mathrm{v}$ poměrně krátkém časovém intervalu mezi lety 1615-1630 (Norman 1980, 257). Oproti klasickým představitelům hlavic tohoto typu, který zastupuje např́klad exemplář z poměrně pozdního kordu ze sbírek Wallace Collection v Londýně (Mann 1962, 323-324, tab. 126; Norman 1980, 257) či dva kordy ze sbírek Hermanna Baumanna v Rothenburgu (Baumann 2010, 505-506), se opět habřinská hlavice $\mathrm{v}$ některých detailech odlišuje. Pláště hlavic typu 38 jsou totiž vesměs členěny do vertikálních polí více či méně výrazným žlábkováním, takže plochy jednotlivých polí jsou konkávní. U námi studovaného exempláře však tomu tak není, nebot' plochy jednotlivých polí jsou v našem prrípadě zcela rovné či nanejvýše v ojedinělých př́ípadech neznatelně konkávní. Celkovým tvarem však danému typu vcelku odpovídá. Analogických hlavic 
nenalezneme v dosud publikovaném materiálu př́liš mnoho. Pokud pomineme již výše zmíněný kord s čepelí připisovanou Matyáši Korvínovi ze sbírek Magyar Nemzeti Múzeum v Budapešti, lze zmínit např́íklad hlavice kordi̊, jež jsou chovány ve sbírce Castello di Monselice (Hayward 1980, 54, kat. č. 162, obr. 123) nebo Museo Nazionale di Ravenna (Boccia 1989, 85-86, tab. IX).

Studovaná zbraň je opatřena taktéž poměrně nezvykle masivní čepelí, jejíž šiřka se směrem k nevýraznému hrotu jen nepatrně parabolicky zužuje, přičemž poměrně krátké ricasso není od čepele výrazněji odsazeno. Tvar čepele, respektive tvar jejího hrotu nás jednoznačně informuje o tom, že čepel byla určena především k sečným útokům, což poněkud odlišuje zbraň z Habřiny od ostatních kordů s podobnými koši, které lze vesměs spíše považovat za zbraně primárně bodné, byt' čepele měly vždy univerzálnější funkci. Tento detail však nemusí být nutně chronologickým ukazatelem, nebot' se širokými čepelemi se setkáváme v průběhu 16 ., a především pak 17. století na vojenských kordech, tedy těch zbraních, pro které se v německé literatuře používá poměrně výstižných termínů „Haudegen“ (např. Müller-Kölling 1984, 69), „Reitschwert“ (např. Oakeshott 2000, 126), případně „Felddegen“ (např. Hilbert 1998, 50). Již od průběhu 16. století se tyto zbraně nepochybně uplatnily ve výzbroji jak soudobé pěchoty, tak jízdy (např. Marek 2006, 148; 2008, 74-76).

Čepel je po obou plochách hrubí opatřena poměrně rozměrnými rytými a následně tauzovanými značkami. Na lícní ploše hrubí je do žlábku čepele situována značka vlevo běžícího zvířete s vyplazeným jazykem a naznačeným okem (obr. 10:1). Na rubové ploše je to pak značka v podobě říšského jablka (obr. 10:2). Značka říšského jablka patří obecně k jedněm z nejrozšiřenějších typů značek na chladných zbraních obecně a signovali jimi své výrobky mečíři takřka naprríč celou Evropou. Ve formě, s jakou se setkáváme na studovaném kordu, ji pak nacházíme v hojné míře také například na dvouručních mečích z konce 16. století, jejichž produkce je obecně shledávána v bavorských, respektive mnichovských a pasovských, popř́padě solingenských dílnách (napr. Wegeli 1905, 37-40; 1929, 35, 44; Diener-Schönberg 1912, 107-109, kat. č. 390-392, 395-398, tab. 75; Ffoulkes 1916, 260-261; Stöcklein 1920, 381; Dufty 1974, 16, tab. 9, 106; Düriegl-Mikula-Sostek 1977, 109, kat. č. 304; Dürieg1 1986, 111, 128, kat. č. 6/54, 6/127; Krenn 1997, 14).

O významu a výkladu značek v podobě vlevo běžícího zvířete zde nemá smysl obšírněji hovořit, nebot' již o nich bylo napsáno mnohé (např. Schmid 1905; 1920; Meyer 1935; Głosek 1973, 32-42; 1984, 50-53; Huther 2007; Žákovský 2008, 474-475; Michalak-Wawrzyniak 2009, 203-204). Tyto značky, které se však ve velkém pravděpodobně již od počátku jejich používání falšovaly po celé Evropě, jsou tradičně nejvíce spojovány s pasovskými a solingenskými dílnami, mezi nimiž probíhaly čilé kompetenční boje o jejich používání (např. Sommer 1925; Weyersberg 1925; 1939). Z počátku mají tyto značky velmi blízkou, až takřka nerozeznatelnou podobnost, ale v průběhu 16. a především pak 17. století jsou pro solingenské výrobky charakteristické značky $\mathrm{v}$ podobě zvířat s nápadně protaženými zadními běhy. To u našeho exempláře postrádáme, byt' taková forma značky, s jakou se setkáváme na studovaném kordu, nemá prozatím v námi známém publikovaném materiálu obdoby.

Kombinace značek v podobě ř́išského jablka a vlevo běžícího zvířete, tzv. pasovského vlka, by nás mohla zlákat přiřadit tento výrobek k produkci pasovské větve mečířské rodiny Standlerů, která zde působila od poloviny 15 . do poloviny 17 . století. Přičemž v době výroby studované zbraně mezi nimi vynikal především Wolfgang Stäntler, který se v pramenech objevuje mezi lety 1580-1617 a jenž se stal dokonce na čas členem pasovské městské rady (např. Schmid 1920, 338). Tato poměrně rozvětvená řemeslnická rodina totiž používala jako svého rodového znaku právě různé formy říšského jablka, přičemž pasovským vlkem se na svých výrobcích odlišovala od svých mnichovských př́buzných (napřr. Stöcklein 1911, 290-291; 1920, 199-202; Schmid 1920, 336-338; Žákovský 2008, 483-485). U starších dlouhých mečů je tato hypotéza pravděpodobná, ale u barokních kordů se tato problematika jeví jako přeci jen o něco složitější. Z řady evropských sbírek totiž známe řadu kordů, které na svých čepelích nesou tuto kombinaci značek, jako např́íklad zbraň ze sbírek Museo Poldi Pezzoli (Boccia-Godoy 1986, 428, kat. č. 575) či kord, který byl před nedávnem dražen v Mnichově. Čepel této zbraně je však navíc ještě opatřena raženou značkou v podobě hlavy mouřenína, která je tradičně spojována s dílnou pasovského 

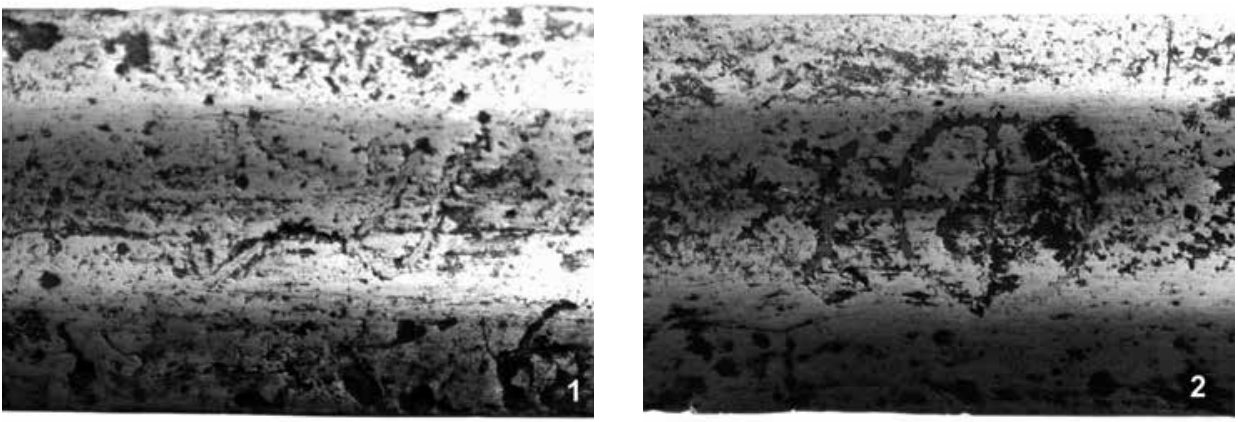

Obr. 10. Detaily tauzovaných značek na čepeli kordu z Habřiny: 1 - značka v podobě vlevo běžícího zvířete, tzv. pasovského vlka; 2 - značka v podobě ŕíšského jablka. Foto P. Žákovský.

Abb. 10. Details der tauschierten Schmiedemarken auf der Klinge des Degens aus Habřina: 1 - Schmiedemarke in Gestalt eines nach links laufenden Tieres, des sog. Passauer Wolfes; 2 - Schmiedemarke in Form eines Reichsapfels. Foto P. Žákovský.

mečíře Petera Munstena (Hermann a kol. 2002, kat. č. 305). Oproti tomu značku ve formě říšského jablka a vlevo běžícího zvířete, tentokráte ve formě typické pro solingenské dílny, kdy zadní běhy zvířete jsou silně stylizovány a jsou znázorněny pouze protažením břišní a hřbetní linie, nalezneme rovněž na zbrani ze sbírek drážd'anské zbrojnice. Vedle těchto značek se na čepeli nachází totiž i ražená signatura solingenského mečiřre Johannese Wundese, která původ zbraně jednoznačně prokazuje (Ehrenthal 1897, 100). Podobně, i když nikoliv tak jednoznačně, jsme na tom při posuzování provenience kordu s typologicky shodnou lícní stranou ochranného koše, jako má kord z Habřiny, a čepelí opatřenou značkami v podobě vlka, říšského jablka a nápisem „1617“, která byla dražena v jedné mnichovské aukční síni. Čepel této zbraně nese na rubové ploše ricassa raženou značku v podobě hlavy Turka, která je opět tradičně spojována se solingenskými mistry (Hermann a kol. 2013, kat. č. 3715). Je tedy těžké, ba přímo nemožné za dnešního stavu poznání rozhodnout, zda se jedná o pasovský či solingenský výrobek.

Pokud by se jednalo o výrobek solingenský, na základě několika vzácně dochovaných zpráv bychom si mohli učinit rámcovou představu, za kolik bylo možné takovou zbraň počátkem 17. století pořídit. $Z$ roku 1628 se nám dochoval například seznam výrobků solingenských mečířů a jejich cen. Mimo jiné se zde uvádí rovněž ,Wolffs Klingen von des Meisters besten Zeichen gepolirt“, každý kus za 45 albusů, „Dergleichen Wolffs Klingen Ungepolirt“, kus za 42 albusů, či „Wolffs Klingen so man bastert nent gepolirt“", kus za 34 albusů. Ve stejné době bylo možné v Solingenu koupit v mečiřské dílně Schwartzů mimo jiné i ,guette wolffs Kling“ za 28 albusů (Sommer 1925, 21). Nejednalo se tudíž o nijak zvlášt' drahé zboží.

Zbraň této německé produkce se $\mathrm{k}$ nám mohla v podstatě dostat několika základními způsoby. Bud' ji s sebou mohl přinést zahraniční člen vojenské jednotky, která v předmětném regionu působila či tudy procházela. Pochopitelně se zbraň do českých zemí mohla dostat také jako vítaný obchodní artikl, nebot' se solingenskými, případně pasovskými výrobky probíhal čilý obchod nejpozději již od vrcholného středověku, jak nás o tom informuje především větší množství vrcholně středověkých mečů nalezených na našem území, které jsou signovány těmito charakteristickými značkami. V masovějším měřítku také nepochybně probíhaly zejména v německých dílnách hromadné nákupy zbraní - nejen pro vojenské oddíly, ale i pro městské a zemské zbrojnice, kde tvořily součást vojenských dodávek -, jimiž byli následně vyzbrojováni členové jednotlivých jednotek (např. Winter 1925, 428-429; Janáček 1961, 151-152; Sterneck 2003, 280, 287, 293). Pro tyto kvalitní výrobky si však jejich budoucí majitelé z řad zámožnějších obyvatel českých zemí mohli zajíždět také sami př́imo ke konkrétním vyhlášeným mečířským mistrům a do výrobních center obecně či na zahraniční trhy. Za př́́klad si zde můžeme vzít záznam z dochovaného nákupního seznamu, který si v roce 1614 zapsal Jan Jiří ze Švamberka. V seznamu, 
který byl pořízen o velikonoční návštěvě jarmarku v rakouském Linci, se totiž dočteme, že si zde tento pán mimo jiné zakoupil i „1 rapír a tulich = 4 kopy 17 gr. 1 den.“(Kubíková 1995, 179).

\section{Interpretace nálezové situace}

Jak již bylo výše zmíněno, byl nález předmětného kordu učiněn na katastru obce Habřina, která se nachází na labské pravobřežní terase mezi městy Hradcem Králové a Jaroměří. Jedná se o území s dlouhou sídelní tradicí sahající do mladší doby kamenné. Na katastrálním území obce je známo také několik poloh s nálezy raně středověké keramiky (Ježek 2007, 561). Hradištní keramika, společně s keramikou vrcholně středověkou a drobnými nálezy obecně datovanými do středověku a raného novověku byly ostatně nalezeny při povrchových průzkumech i v blízkém okolí studovaného nálezového souboru (např. Bláha-Kalferst-Sigl 2004, 20; 2005, 5). Sama ves je pak prvně zmíněna $v$ písemných pramenech $\mathrm{k}$ roku 1357, kdy se po ní píše Konata z Habřiny (Conate de Habrzyna), zmíněn je i Čeněk z Hustířan, který sám roku 1376 užívá predikát z Habřiny (LC I/1, 29). Díky přítomnosti farního kostela sv. Václava, na návrší východně od obce, je Habřina často zmiňována $v$ konfirmačních a erekčních knihách. Vesnice byla v průběhu 14. a 15. století v držení místní šlechty užívající přídomku z Hustiřan, či Habřiny. V roce 1533 vesnici od Aleše Rodovského z Hustíranan koupil Mikuláš Trčka z Lípy, díky čemuž byla připojena k smiřickému panství (Sedláček 1883, 242; 1909, 202; Horyna 1968, 145-146). Po násilné smrti Adama Erdmana Trčky z Lípy v roce 1634 v Chebu připadlo o dva roky později panství generálu Matyášovi Gallasovi, který jej držel až do své smrti v roce 1647 (Rebitsch 2013, 224-225).

Na katastrálním území vsi Habřina jsou známy rovněž tři opevněné lokality. Severně od vesnice na zalesněném návrší se nachází pozůstatky hradu neznámého jména, který bývá označován podle pomístního názvu Vražba. Archeologický výzkum zjistil krátkodobé osídlení lokality během druhé poloviny 13. století (Sigl 1979; Křížek-Řezník 1992, 100-101; Durdík 1999, 607; Kosař 2015, 8-11). Na protilehlém vršku byl vystavěn hrad Rotemberk, jehož počátky jsou kladeny do 14. století (Sedláček 1883, 237). Prvně je výslovně zmíněn až k roku 1511, ale již roku 1542 je připomínán jako pustý (Kalferst 1993, 100; Křížek-Řezník 1992, 72; Durdík 1999, 480; Kosař 2015, 8-11). Přímo v intravilánu vsi se nachází tvrziště obdélného půdorysu o rozměrech $15 \times 10 \mathrm{~m}$. Ačkoliv se ves objevuje v řadě predikátů, sídlo výslovně zmíněno není. Jeho opuštění je kladeno nejpozději do období připojení vsi ke smiřickému panství (Sedláček 1883, 242; Křížek-Řezník 1992, 18; Svoboda-Úlovec et al. 1998, 173).

Vzhledem k zániku všech výše uvedených panských sídel před polovinou 16. století nelze tato spojovat s nálezem kordu. Ztrátu zbraně lze tedy dávat spíše do souvislosti s provozem na místní komunikaci, která překračovala tok Hustířanky zřejmě někde v místech nynějšího mostu. Hypoteticky se tak můžeme zamyslet nad způsobem či prŕíčnami, proč se kord dostal do koryta Hustířanky, a proč nebyl svým tehdejším majitelem vyzvednut, přestože při případné náhodné ztrátě nepředstavoval poměrně mělký a úzký tok zase takovou překážku v jeho hledání. Obecně se dá říci, že nálezy zbraní v říčních korytech jsou celoevropským fenoménem, přičemž příčiny archeologizace jednotlivých zbraní či celých souborů musíme vždy posuzovat zcela individuálně a zřejmě pro ně neplatí nějaká obecná pravidla. Většinou se zbraně v období vrcholného středověku a raného novověku dostávaly do koryt vodních toků patrně zcela nezáměrně v důsledku destrukce vodních dopravních prostředkủ či při ne zcela poklidném překonávání ŕíčního toku. V určitých specifických situacích se militaria mohla dostat do vodních koryt i při náhlých záplavách, kdy byly spláchnuty z blízkých břehů. V interpretaci jednotlivých nálezů a jejich nálezových okolností nás navíc výrazně limituje fakt, že ve větších vodních tocích, kde máme co do činění s prudším vodním proudem, mohly být tyto předměty transportovány i na poměrně velké vzdálenosti. V podstatě tedy nevíme, kde se vlastně do vodního toku dostaly. To se však, vzhledem k charakteru toku Hustíranky, netýká našeho nálezu. Můžeme se důvodně domnívat, že místo nálezu celého souboru je i místem jeho vlastní archeologické transformace. Vzhledem $\mathrm{k}$ absenci či přinejmenším nemožnosti přesné identifikace materiálu, který je ve zprávě o nálezu uváděn, však nejsme schopni rozhodnout, zda tyto předměty tvořily původně jeden celek nebo 
se do koryta říčky dostaly zcela nezávisle na sobě. Pokud by nálezový soubor tvořil jeden celek, jednalo by se nepochybně o doklad nějaké tragické události, ke které zde mohlo dojít během válečného střetu. Př́tomnost poboční zbraně a torza ochranné zbroje, v našem př́ípadě udávané torzo přilby, by tuto hypotézu jen podporovala. Také podkovy by mohly být pozůstatkem po nebohém jezdeckém zvířeti, které uhynulo a bylo do vodního toku vhozeno či utonulo př́mo v něm. Samozřejmě i udávaný kosterní materiál by mohl být spojen s tímto hypotetickým neštastným zvířetem. Dá se předpokládat, že pokud by se v daném případě jednalo o pozůstatky lidského skeletu, bylo by to ve zprávě zmíněno. Ovšem vyloučit se nedá vůbec nic. Pochopitelně i př́padná náhodná ztráta pouhého kordu by nezůstala bez reakce svého majitele, který by se jí nepochybně pokoušel nalézt a získat zpět. Ve větších a hlubších vodních tocích je takové hledání většinou předem odsouzeno $\mathrm{k}$ neúspěchu. U vodního toku, který se dá takřka překročit suchou nohou, však s komplikacemi rázu hloubky toku a síly jeho proudu kalkulovat nemusíme. Snad jen $\mathrm{v}$ případě nějakého nenadálého rychlého a masivního rozvodnění tohoto toku by se situace mohla výrazněji zkomplikovat. Zdá se tedy, že kord zůstal v korytě říčky Hustíranky z jiného důvodu. Opět se nabízí spojení tohoto nálezu s případnými vojenskými aktivitami v daném mikroregionu - majitel zbraně mohl zahynout během válečného střetu, a proto zbraň zůstala ležet ve vodním toku.

Pokud tuto hypotetickou možnost přijmeme jako alespoň jednu z možností, lze s ohledem na dataci zbraně spojit její uložení do koryta místní vodoteče s pohyby a možnými drobnými vojenskými šarvátkami v průběhu konfliktu, obecně známého jako třicetiletá válka. Během prvních válečných let zůstával prostor Hradecka a Jaroměřska sice ušetřen přímých vojenských střetů, avšak již od potlačení stavovského povstání se obě města stávala místem, kudy často pochodovala či kde tábořila císařská vojska, která musela být vydržována. V roce 1628 vypuklo navíc v severovýchodních Čechách povstání, které postihlo zejména prostor trčkovských panství (Matouš 2001; Hofman 2007). Ačkoliv bylo již v průběhu března a dubna potlačeno, nelze jeho rozsah podceňovat, nebot' si vyžádalo i přítomnost samotného Albrechta z Valdštejna.

Oblast se do př́imých válečných stř̌etů, zachycených písemnými prameny, dostala až v roce 1639, kdy byl 17. června švédskými vojsky pod vedením generála Banéra dobyt Hradec Králové a následně obsazena Jaroměř, Smiřice a jiná východočeská města (Knnap 1887, 103; Mikulka 1994, 19). Následujícího roku 20. února byl Hradec dobyt zpět, díky čemuž se stáhly švédské oddíly i z okolních měst. Poté co vtrhl generál Torstenson v roce 1643 do Čech, tábořil s císařským vojskem jeho protivník Matyáš Gallas u Hradce Králové. K významnější srážce však nedošlo. V době po bitvě u Jankova se 7. ř́ína 1645 pokusila švédská vojska dobýt Hradec Králové, obléhání však skončilo nezdarem a Torstenson musel ve dvou proudech odtáhnout směrem na Smiřice a Jičín. Jaroměř byla v té době švédskými vojsky opět okupována (Knnap 1887, 105). O rok později tímto krajem táhl švédský generál Wittenberk, což bylo opět spojeno s pleněním okolí, které umocnila porážka císařských vojsk u Police nad Metují (Solař 1870, 133; Mertlíková-Č́ižek 2004, 104). Snad právě s pohybem těchto vojenských a zásobovacích oddílů v průběhu 20.-40. let 17. století bychom mohli hypoteticky spojit nález studované zbraně, která mohla být ztracena při písemnými prameny nezachycené šarvátce, $\mathrm{k}$ jakým nepochybně mezi zásobovacími oddíly a obyvatelstvem postižených oblastí nezřídka docházelo. Pochopitelně spojit tento nález s jednou z výše uvedených konkrétních vojenských kampaní není, a patrně také nikdy nebude možné.

Více informací nám tedy tento ojedinělý nález prozatím neposkytuje. Jednoznačně však ukazuje, že by předmětné místo nálezu u mostu přes říčku Hustířanku mělo být v budoucnu sledováno po archeologické stránce se zvýšenou pozorností. Při případných stavebních úpravách mostu, vozovky či samotného říčního koryta by totiž mohlo dojít k dalším nálezům, které by nám snad osvětlily, co se v daném místě v první polovině 17. století skutečně odehrálo.

Text studie vznikl v rámci Programu výzkumné činnosti Archeologického ústavu Akademie věd České republiky, Brno, v. v. i., na léta 2012-2017. 


\section{Prameny a literatura}

LC: Libri confirmationum ad beneficia ecclesiastica pragensem per archidioecesim I/1 1354-1362 (Ed. Franciscus Antonius Tingl). Pragae 1867.

BAUMANN, W., 2010: Historische Waffen und Rüstungen. Sammlung Hermann Baumann. Katalog zur Waffensammlung der Stiftung Baumann in den Räumen des Reichsstadtmuseums in Rothenburg o. d. Tauber. Rothenburg.

BLÁHA, R.-KALFERST, J.-SIGL, J., 2004: Přírůstky archeologické sbírky hradeckého muzea v letech 2000-2003 - Acquisitions of the archaeological collections of the Hradec-Králové museum in 20002003, ZMHK 30 - Supplementum, 3-142.

- 2005: Přírůstky archeologické sbírky hradeckého muzea v roce 2004 - Recent accessions of the Archaeological collections of the Hradec-Králové Museum in 2004, ZMHK 31, 3-18.

BLAIR, C., 1962: European \& American Arms c. 1100-1850. New York.

BOCCIA, L. G., 1989: L'Oploteca nel Museo Nazionale di Ravenna. Tre secoli di armi antiche. Ravenna.

BOCCIA, L. G.-GODOY, J. A., 1986: Armi europee dal medioevo all' età moderna II. Armid el vicino e medio oriente. In: Museo Poldi Pezzoli. Armeria II (Slavich, P., ed.), 423-859. Milano.

BOEHEIM, W., 1889: Führer durch die Waffen-Sammlung. Wien.

- 1894: Album hervorragender Gegenstände aus der Waffensammlung des allerhöchsten Kaiserhauses. Wien.

DIENER-SCHÖNBERG, A., 1912: Die Waffen der Wartburg. Berlin.

DUFTY, A. R., 1974: European Swords and Daggers in the Tower of London. London.

DURDÍK, T., 1999: Ilustrovaná encyklopedie českých hradů. Praha.

DÜRIEGL, G., ed., 1986: Wehrhafte Stadt. Das Wiener Bürgerliche Zeughaus im 15. und 16. Jahrhundert. Wien.

DÜRIEGL, G.-MIKULA, R.-SOSTEK, M., edd., 1977: Das Wiener Bürgerliche Zeughaus. Rüstungen und Waffen aus fünf Jahrhunderten. Wien.

EHRENTHAL von, M., 1897: Führer durch das Königliche Historische Museum zu Dresden. Dresden.

FFOULKES, CH. J., 1916: Inventory and Survey of the Armouries of the Tower of London. Volume II: Offensive Arms. London.

FISCHER, T., 1936: Jagdkammer des Reichsgrafen Ritter von Kaunitz. II. Teil. Gotischer Feldharnisch, Rüstungen, Schwerter, Fahnen, Standarten, Pulverwaffen und Diverses aus hocharistokratischem Besitz. Luzern.

FORRER, R., 1905: Die Schwerter und Schwertknäufe der Sammlung Carl von Schwerzenbach - Bregenz. Mit einer Geschichte von Schwert und Dolch. Leipzig.

GŁOSEK, M., 1973: Znaki i napisy na mieczach średniowiecznych w Polsce. Wrocław - Warszawa Kraków - Gdańsk.

- 1984: Miecze środkowoeuropejskie z X-XV w. Warszawa.

HAENEL, E., 1923: Kostbare Waffen aus der Dresdner Rüstkammer. Leipzig.

HAYWARD, J., 1980: Larmeria del Castello di Monselice. Venezia.

HERMANN, F. a kol., 2002: Hermann, F.-Hermann, W.-Rief, T.-Wagner, E. L., Hermann Historica München. 42. Auktion. München.

- 2007: Hermann Historica München. 52. Auktion. Alte Waffen, Antiken, Jagdliche, Varia. München.

- 2013: Hermann Historica München. 67. Auktion. Antiken, Alte Waffen, Jagdliches und Kunsthandwerk. München.

HERMANN, W.-WAGNER, E. L.-CZERNY, P., 1988: Hermann Historica OHG München. 19. Auktion. Alte Waffen, Order und Ehrenzeichen, Militaria, geschichtliche Objekte. München.

HILBERT, K., 1998: Blankwaffen aus drei Jahrhunderten. Berlin.

HOFMAN, M., 2007: Ke strategii a organizaci povstání na trčkovských panstvích roku 1628, Orlické hory a Podorlicko 14, 285-298.

HORYNA, V., ed., 1968: Vlastivěda Královéhradecka. Kulturní a hospodářský snímek okresu. Hradec Králové.

HUTHER, H., 2007: Die Passauer Wolfsklingen. Legende und Wirklichkeit. Passau.

JANÁČEK, J., 1961: Řemeslná výroba v českých městech v 16. století. Praha.

JEŽEK, M., 2007: Jaroměřsko v raném středověku - The Jaroměř region in the Early Middle Ages, AR LIX, 523-570.

KALFERST, J., 1993: Zjišt'ovací výzkum na hradě Rotemberku, k. ú. Habřina, ZMHK 19, 100-106.

KALMÁR, J., 1971: Régi magyar fegyverek. Budapest.

KNNAP, A., 1887: Paměti královského věnného města Jaroměře nad Labem. Jaroměř. 
KOČAN, V.-GRONSKÝ, R., 2014: Zbrojnice na Státním zámku Lysice. Poklady zbrojnic na hradech a zámcích ve správě Národního památkového ústavu. Brno.

KONZE, M.-SAMARITER, R., 2014: Der Stralsunder Laufgraben von 1628 - verschüttete Söldner und Waffen in situ. Festungsbau im Süden der Hansestadt (Quartier Frankenhof) im Spiegel archäologischer Befunde und historischer Quellen. In: Schlachtfeld und Massengrab. Spektren interdisziplinärer Auswertung von Orten der Gewalt. Forschungen zur Archäologie im Land Brandenburg 15 (Eickhoff, S.-Schopper, F., edd.), 145-168. Wünsdorf.

KOSA ̌̌, M., 2015: Hrady na Trotince a Hustířance. The Castles on Trotinka and Hustíranka, Východočeské listy historické 34, 5-14.

KRENN, P., 1997: Schwert und Spiess. Ried im Innkreis.

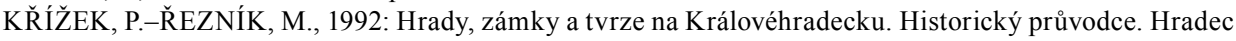
Králové.

LUGOSI, J.-TEMESVÁRY, F., 1988: Kardok. Budapest.

MANN, J., 1962: European Arms and Armour II. Arms. Wallace Collection Catalogues. London.

MAREK, L., 2006: Szesnastowieczny miecz ze Środy Śląskiej, Silesia Antiqua 43, 145-155.

- 2008: Broń biała na Śląsku. XIV-XVI wiek. Wrocław.

MATOUŠ, V., 2001: Velká selská rebelie na Opočenském panství roku 1628, Orlické hory a Podorlicko 11, $160-165$.

MATOUŠEK, V., 2011: Terénní studium bojišt’ třicetileté války na území České republiky. In: Bitva u Rakovníka 1620 (Blažková, K., ed.), 72-80. Rakovník - Chrášt’any.

- 2011a: Zpráva o 1. sezoně systematického archeologického výzkumu bojiště z roku 1621 u Rozvadova, Sborník Muzea Českého lesa v Tachově 32/11, 3-13.

MEIJER jr., D. C., 2013: The Amsterdam Civic Guard Portraits within and outside the New Rijksmuseum, Pt. I, Journal of Historians of Netherlandish Art 5:1, 1-26.

MERTLÍKOVÁ, O.-ČÍŽEK, J., 2004: Důsledky válečných událostí na vývoj Jaroměře v období třicetileté války. In: Věnná města za třicetileté války a jejich poválečná obnova. Sborník př́ispěvků z konference konané ve dnech 4.-5. května 2004 (Kilián, J., ed.), 101-110. Mělník.

MEYER, S., 1935: Znaki „wilka“ na głowniach, Broń i barwa II, 241-242.

MICHALAK, A.-WAWRZYNIAK, P., 2009: Między bronią a narzędziem, czyli w co przekuto miecz ze Świebodzina?, Acta Militaria Mediaevalia V, 197-212.

MIKULKA, J., 1994: Dějiny Hradce Králové II/2. Hradec Králové.

MÜLlER, H.-KÖLlING, H., 1984: Europäische Hieb- und Stichwaffen aus der Sammlung des Museums für Deutsche Geschichte. Berlin.

NICKEL, H., 1974: Ullstein Waffenbuch. Eine kulturhistorische Waffenkunde mit Markenverzeichnis. Berlin - Frankfurt am Main - Wien.

NORDSTRÖM, L., 1984: White Arms of the Royal Armoury. Stockholm.

NORMAN, A. V. B., 1980: The Rapier and Small-Sword, 1460-1820. London - Melbourne - New York.

NORTH, A., 1993: From rapier to smallsword. In: Swords and hilt weapons (Cope, A., ed.), 58-71. London.

OAKESHOTT, E., 2000: European Weapons and Armour from the Renaissance to the Industrial Revolution. Woodbridge.

REBITSCH, R., 2013: Matyáš Gallas (1588-1647). Císařský generál a Valdštejnův „dědic“. Praha.

SEDLÁČEK, A., 1883: Hrady, zámky a tvrze království českého. Díl II. Hradecko. Praha.

- 1909: Místopisný slovník historický Království českého. Praha.

SEITZ, H., 1965: Blankwaffen I. Geschichte und Typenentwicklung im europäischen Kulturbereich. Von der prähistorischen Zeit bis zum Ende des 16. Jahrhunderts. Braunschweig.

SCHMID, W. M., 1905: Passauer Waffenwesen. I. Klingenindustrie, Zeitschrift für historische Waffenkunde III, 312-316.

- 1920: Passauer Waffenwesen. III. Klingenbeschau und -marken, Zeitschrift für historische Waffenkunde VIII, 317-342.

SIGL, J., 1979: Zjištovací výzkum na středověkém hrádku v poloze „Vražba“ u Habřiny, okr. Hradec Králové, Zpravodaj Krajského muzea východních Čech 6, 27-33.

SOLAŘ, J. N., 1870: Dějepis Hradce Králové nad Labem a biskupství hradeckého. Praha.

SOMMER, F., 1925: Der Klingenhandel der Solinger Handwerksbrüder im 15., 16. und 17. Jahrhundert, Zeitschrift für historische Waffen- und Kostümkunde X, Neue Folge 1, 13-25.

STERNECK, T., 2003: Moravská zemská zbrojnice v Brně na přelomu 16. a 17. století, BMD 17, $273-309$.

STÖCKLEIN, H., 1911: Münchener Klingenschmiede, Zeitschrift für historische Waffenkunde V, $286-291$.

- 1920: Münchener Klingenschmiede, Zeitschrift für historische Waffenkunde VIII, 198-205, 370-385.

SVOBODA, L.-ÚLOVEC, J., et al., 1998: Encyklopedie českých tvrzí I. (A-J). Praha. 
SZENDREI, J., 1896: Ungarische kriegsgeschichtliche Denkmäler in der Millenniums-Landes-Ausstellung. Budapest.

ŠÁMAL, Z., 2011: Archeologové na bojišti. Několik poznámek k detektorovému průzkumu rakovnického bojiště z roku 1620. In: Bitva u Rakovníka 1620 (Blažková, K., ed.), 50-59. Rakovník - Chrášt’any.

WEGELI, R., 1905: Katalog der Waffen-Sammlung im Zeughause zu Solothurn. Solothurn.

- 1929: Inventar der Waffensammlung des Bernischen Historischen Museums in Bern II. Schwerter und Dolche. Bern.

WEYERSBERG, A., 1925: Die in den privilegierten Handwerken der Solinger Klingenindustrie vertretenen Familiennames, Zeitschrift für historische Waffen- und Kostümkunde X, Neue Folge 1, 224-225.

- 1926: Solinger Schwertschmiede des 16. und 17. Jahrhunderts und ihre Erzeugnisse. Solingen.

- 1939: Der Wolf als Klingenzeichen und im Klingenhandel, Zeitschrift für historische Waffen- und Kostümkunde XV, Neue Folge 6, 42-44.

WINTER, Z., 1925: Z městských živností. Praha.

ŽÁKOVSKÝ, P., 2008: Značené vrcholně a pozdně stř̌edověké dlouhé meče ze sbírek Městského muzea v Broumově - Gekennzeichnete Langschwerter des Hoch- und Spätmittelalters aus den Sammlungen des Städtischen Museums in Broumov, AH 33, 471-490.

- 2011: Středověké a raně novověké chladné zbraně ze sbírek Městského muzea v Moravském Krumlově Mittelalterliche und frühneuzeitliche kalte Waffen aus den Sammlungen des Stadtmuseums Moravský Krumlov (Mährisch Kromau). In: Hrad jako technický problém. Technologie a formy výstavby středověkých opevněných sídel. Archaeologia mediaevalis Moravica et Silesiana II/2010 (Měřínský, Z., ed.), 127-188. Brno.

СВЕШНІКОВ, І. К., 1992: Битва під Берестечком. Львів.

\section{Zusammenfassung}

\section{Der Fund des Barockdegens aus Habřina in der ostböhmischen Region Jaroměr}

Im Jahr 1922 hat man im Kataster der Gemeinde Habřina im Flussbett der Hustíranka archäologisches Material gefunden, das aus zwei Hufeisen, einem angeblichen Helmtorso, einem Degen (the rapier) und aus nicht näher spezifiziertem Skelettmaterial bestand. Von diesen Gegenständen konnte bis heute lediglich der schöne und fast noch komplett erhaltene Barockdegen mit einer Gesamtlänge von $1110 \mathrm{~mm}$ und einem Gewicht von $1242 \mathrm{~g}$ eindeutig identifiziert werden (Abb. 3-6). Die Waffe ist mit einem Korbhandschutz (the hilt) ausgestattet, der nach A. V. B. Norman als Typ 31 klassifiziert werden kann, der dessen Vorkommen vor allem in der ersten Hälfte des 17. Jahrhunderts sieht (Norman 1980, 94-95). Zu dem hier vorliegenden Degen findet man in den Weltsammlungen eine ganze Reihe ähnlicher Waffen, wobei dessen nächste Analogie in einer Waffe gesehen werden kann, die früher Bestandteil der Sammlungen des kaiserlichen Zeughauses war und heute im Budapester Magyar Nemzeti Múzeum aufbewahrt wird und traditionell Matthisa Corvinus zugeschrieben wird (z.B. Boeheim 1889, 30, Kat.-Nr. 87; 1894, 5-6, Taf. VII:3; Szendrei 1896, 295-296, Kat.-Nr. 1189; Kalmár 1971, 68, Abb. 118-119). Bei der Anfertigung dieser Waffe hatte man offensichtlich eine ältere Schwertklinge verwendet, die irgendwann zu Beginn des 17. Jahrhunderts mit einem neuen Griffteil versehen wurde, das fast eine Analogie zum Degen aus Habřina darstellt (Abb. 9).

Die Klinge des Degens aus Habřina ist auf beiden Seiten mit relativ großen tauschierten Schmiedemarken versehen. Eine Seite trägt eine Schmiedemarke mit der Gestalt eines nach links laufenden Tieres, d.h. eine Schmiedemarke in Gestalt des sog. Passauer Wolfes, und die andere Seite trägt dann eine Schmiedemarke, welche die Form eines Reichsapfels hat. Diese Schmiedemarken werden für gewöhnlich den Werkstätten aus Passau oder Solingen zugeschrieben. In diesen Produktionszentren wurde offenbar an der Wende des 16. und 17. Jahrhunderts auch der Degen aus Habřina hergestellt.

Im Hinblick darauf, dass wir über keinerlei Informationen bezüglich den näheren Fundumständen zu dieser Waffe vefügen, kann man nur hypothetisch annehmen, dass sie im Zusam- 
menhang mit den bewegten Ereignissen des Dreißigjährigen Krieges verloren ging, von dem das betreffende Gebiet besonders in den vierziger Jahren des 17. Jahrhunderts heimgesucht wurde.

Der Text der vorliegenden Studie entstand im Rahmen des Programms Forschungstätigkeiten des Archäologischen Institus der Akademie der Wissenschaften der Tschechischen Republik, Brno, v. v.i., für die Jahre 2012-2017.

Mgr. Petr Žákovský, Ph.D., Archeologický ústav AV ČR, Brno, v.v. i., Čechyňská 363/19, 60200 Brno, Česká republika,zakovsky@arub.cz

Mgr. Pavel Drnovský, Katedra archeologie Filozofické fakulty Univerzity Hradec Králové, Rokitanského 62, 50003 Hradec Králové, Česká republika, pavel.drnovsky@uhk.cz 
